\title{
THE PHYSICAL PROPERTIES OF BEAN COMMON MOSAIC VIRUS DISTRIBUTED IN UKRAINE
}

\author{
A. Kyrychenko, V. Prylipko \\ Zabolotny Institute of Microbiology and Virology, NAS of Ukraine, \\ 154 Acad. Zabolotny Str., Kyiv, 03143, Ukraine \\ e-mail: kirangel.07@meta.ua
}

\begin{abstract}
Bean common mosaic virus (BCMV) is one of the most widespread in bean crops viruses belonging to Potyviridae family. The present study was conducted to know the physical properties of BCMV distributed in Ukraine. Methods. Visual diagnosis, biological testing of the virus, electron microscopy, polymerase chain reaction with reverse transcription (RT-PCR). Results. The presence of BCMV in the plants showing clear viral infection symptoms was established by RT-PCR. The virus was purified from BCMV-infected bean tissues by modified procedure involved clearing with $2.5 \%$ of Triton X-100 and concentrating by centrifugation with linear 10-50\% sucrose gradient in $0.1 \mathrm{M}$ Tris-thioglycolic acid. The yield of purified virus was 3-4 mg/100 g of infected leaves. The determination of physical properties using the same buffer showed that infectivity of crude was lost by heating at $60-65^{\circ} \mathrm{C}$ for 10 minutes, dilution end point (DEP) was $10^{-4}$ and longevity in vitro (LIV) was $1-2$ days at $4^{\circ} \mathrm{C}$ or 3-4 days at $20-25^{\circ} \mathrm{C}$ storage in vitro. This virus is long flexuous filamentous particles approximately 740-750 $\mathrm{nm}$ in size. Conclusions. The results added physical properties to the knowledge of BCMV which helps in determining management strategies against the virus.
\end{abstract}

Keywords: bean common mosaic virus, polymerase chain reaction with reverse transcription, thermal inactivation point, dilution end point, longevity in vitro.

Bean common mosaic virus (BCMV) is one of the most widespread in bean crops and economically important in bean production virus belonging to genus Potyvirus of Potyviridae family. Prior to 1934, BCMV was variously named Bean virus 1 , Bean mosaic virus, and Phaseolus virus 1 $[1,2]$. To differentiate the virus from Bean yellow mosaic virus, the original name - Bean mosaic virus was changed as Bean common mosaic virus. Bean common mosaic caused by BCMV was first observed in 1894 in Russia by Iwanowski [3]. Since that time mosaic has been reported in many countries throughout the world and is almost always present wherever susceptible bean varieties are grown. The originally identified BCMV isolate was lost, and US-1 strain is considered to be typical BCMV strain [4]. There are at least eight biological pathotypes or strains of BCMV with different biological and genetic properties $[5,6]$.

In Ukraine it was established the prevalence of the viral disease in the cultivation area of different bean varieties and unveiled that diseased plants were infected by BCMV. The results of host plant range investigating and reaction of selected indicator plants to mechanical inoculation indicated that obtained isolate differs from the BCMV strains circulating in Ukraine earlier [7]. Based on a biological test on bean differentials, the isolate was assigned to pathogroup VII despite the fact that strain differed markedly from the standard strains in symptoms producing on differential groups IV and $\mathrm{V}[8]$.

The present experiments were carried out in order to study the physical properties like thermal inactivation point (TIP), dilution end point (DEP) and longevity in vitro (LIV) of BCMV distributed in Ukraine. The data obtained will allow us to more fully characterize the studying strain, since the searching of the physical properties of the virus is an integral part of the virus or strain (isolate) study.

\section{MATERIALS AND METHODS}

Virus inoculum. Pure virus culture was raised on Phaseolus vulgaris plants grown in glass house. The BCMV infected leaves showing mosaic symptoms were used as fresh inoculum for extraction of infective crude sap.

Mechanical inoculation. Mechanical inoculation was carried out in pre-chilled pestle and mortar by extracted sap (in cold $0.1 \mathrm{M}$ phosphate buffer, $\mathrm{pH} 7.2(1: 10 \mathrm{w} / \mathrm{v}))$ rubbing onto leaves, predusted with carborundum. The appearance and the 
development of virus symptoms were inspected periodically during 2-3 weeks after inoculation. The infection status of all inoculated plants was verified by Reverse Transcription and Polymerase Chain Reaction (RT-PCR).

Electron microscopy. Electron microscopic observations of purified viruses from infected bean leaves were carried out using an electron microscope JEM 1400. A drop of 1:100 dilution of purified virus preparation was placed on formvar coated grids, incubated for 30 seconds, washed with distilled water and stained with $2 \%$ uranyl acetate or with $1 \%$ potassium phosphotungstate.

Virus purification. The virus particles were purified according to $\mathrm{H}$. Huttinga virus purification method [9] with some modifications. The virus was purified from freshly harvested tissue. Infected tissues were extracted when symptoms were classified as optimal. Tissue $(100 \mathrm{~g})$ was homogenized in 3 volumes of chilled $0.1 \mathrm{M}$ Tris-thioglycolic acid ( $\mathrm{pH}$ 9), containing 0.005 ethylenediaminetetraacetate sodium salt (EDTA) and $0.5 \mathrm{M}$ urea instead of carbon tetrachloride and chloroform as author recommended. Virus was sedimented by centrifuging at different centrifugal forces, and resuspended in Tris $\mathrm{HCl}(\mathrm{pH} 9$ ) buffers. The preparation was purified with $2.5 \%(\mathrm{v} / \mathrm{v})$ of Triton X-100 adding. Two cycles of differential centrifuging $(90 \mathrm{~min}$ at $70000 \mathrm{~g}$ and $10 \mathrm{~min}$ at $8000 \mathrm{~g}$ ) was performed. The supernatant was then layered onto a preformed linear 10-50\% sucrose gradient in $0.1 \mathrm{M}$ Tris-thioglycolic acid and centrifuged at $90000 \mathrm{~g}$ for $120 \mathrm{~min}$. The light-scattering band was withdrawn; the virus was pelleted by centrifugation and checked by infectivity testing and electron microscopy. All purification steps were done at $0-4^{\circ} \mathrm{C}$. Infectivity of purified virus was checked by inoculating into healthy Phaseolus vulgaris plants.

Reverse transcriptase polymerase chain reaction. Total RNA was isolated from symptomatic or healthy leaf tissues using AmpliSens RiboSorb DNA/RNA extraction kit. PCR test kit AmpliSens Reverta $\mathrm{L}$ was used to generate cDNA according to the manufacturer's instructions. The samples were assayed by the RT-PCR using specific primers, which amplify $340 \mathrm{bp}$ fragments of 3 '-end of coat protein gene [10].

The reaction mixture for the PCR (a volume of $20 \mu 1)$ contained: $1 \times$ PCR buffer with $1.5 \mathrm{mM} \mathrm{MgCl}{ }_{2}, 0.2 \mathrm{mM}$ dNTPs, $10-50 \mathrm{ng}$ of cDNA, $0.5 \mathrm{U}$ Taq polymerase. All primers were used at final concentration of 5 pmol per $20 \mu \mathrm{l}$ in PCR reaction. The amplification was performed in DNA Thermocyclers «Tertsyk» TP4-PCR01 .

The next cycling conditions were used for primer set: denaturation at $94^{\circ} \mathrm{C}$ for $5 \mathrm{~min}, 35 \mathrm{cyc}-$ les of amplification $\left(94^{\circ} \mathrm{C}\right.$ for $30 \mathrm{~s}, 60^{\circ} \mathrm{C}$ for $30 \mathrm{~s}$, and $72^{\circ} \mathrm{C}$ for $30 \mathrm{~s}$ ), and a final extension at $72^{\circ} \mathrm{C}$ for $7 \mathrm{~min}$. The PCR fragments were verified in a $1.5 \%(\mathrm{w} / \mathrm{vol})$ non-denaturing agarose gel after ethidium bromide $(0.5 \mathrm{mg} / \mathrm{ml})$ staining. The gel was run at 120 volts and maximum current for 45 min before being viewed under UV light and photographed.

Physical properties in crude sap. The experiments were carried out following the methodology described by Noordam (1973) [11]. Virus infected leaves of about one month-old bean plants were macerated using a mortar and pestle. The macerated tissue was squeezed through a double layer of cheesecloth in order to extract plant sap which was used for all the determinations of physical properties. Phaseolus vulgaris L. var. Monroe was used as the local lesion assay plant.

Dilution end point (DEP). Infective viruscontaining sap $(2 \mathrm{ml})$ was diluted in buffer from $10^{-1}$ to $10^{-7}$ using serial dilution technique. For infectivity test the leaves of the assay plants were inoculated with each virus dilution and rinsed 10 min after inoculation. The assay plants were kept in the greenhouse and were observed daily for development of symptoms.

Thermal inactivation point (TIP). Two milliliter portions of fresh virus-containing sap were heated in a water bath under different temperatures in the range from 50 to $70^{\circ} \mathrm{C}$, with $10^{\circ} \mathrm{C}$ interval for $10 \mathrm{~min}$. The samples were then allowed to cool in ice and were checked for infectivity by inoculating leaves of the bean Monroe seedlings (five plants for each temperature treatment). Untreated sap was used as a positive control and only buffer as negative control, treated plants were kept in the greenhouse for the symptoms manifestation.

Longevity in vitro (LIV). Ten milliliter of infective sap was stored in test tubes at $4^{\circ} \mathrm{C}$ and $20-25^{\circ} \mathrm{C}$ (room temperature). Infectivity of the sap was checked daily during 9 days after storage by removing $1 \mathrm{ml}$ portions and inoculating the assay plants. Freshly extracted sap was a positive control for each experiment. Observations on symptoms expressed and time taken for symptoms expression were recorded. 


\section{RESULTS}

BCMV causes common mosaic and necrosis in Phaseolus vulgaris plants. The type of symptom produced is determined by the strain of BCMV, temperature and the host genotype. Symptoms associated with common mosaic include leaf rolling or blistering, light and dark-green patches on the leaf (green mosaic), chlorotic vein banding, yellow mosaic and growth reduction (Fig. 1).

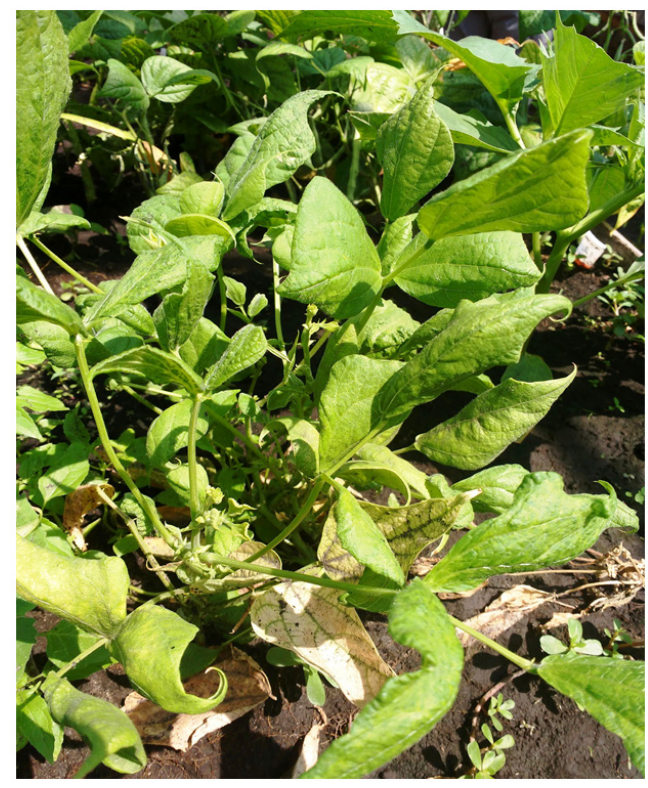

F i g. 1. Leaf curling and malformation induced by BCMV infection on Phaseolus vulgaris plants

In plants showing clear viral infection symptoms the presence of BCMV was established by RT-PCR. The amplification of the CP gene with $\mathrm{BCMV}$ primers generated a single DNA fragment of the expected size ( $\sim 340 \mathrm{bp})$. Amplification did not occur in the negative control (PCR mixture with molecular water) (Fig. 2).

As is known, that potyviruses tend to aggregate and precipitate and it is difficult to purify them. Taking this into account, during virus purification the modification of Huttinga method was made to overcome the two main difficulties - virus aggregation and virus fragmentation. The modified purification method permitted the isolation of BCMV with a high degree of purity. The yield of the virus was higher (4 mg/100 $\mathrm{mg}$ of fresh leaves) than that obtained by Huttinga method, however, the virus significantly lost its infectivity (the dates not presented). Thus, the purification method used in the study ensured the removal of cell debris avoiding significant virus losses and allowed to reduce aggregation complicating further purification steps as well as to get sufficient yield of the virus.

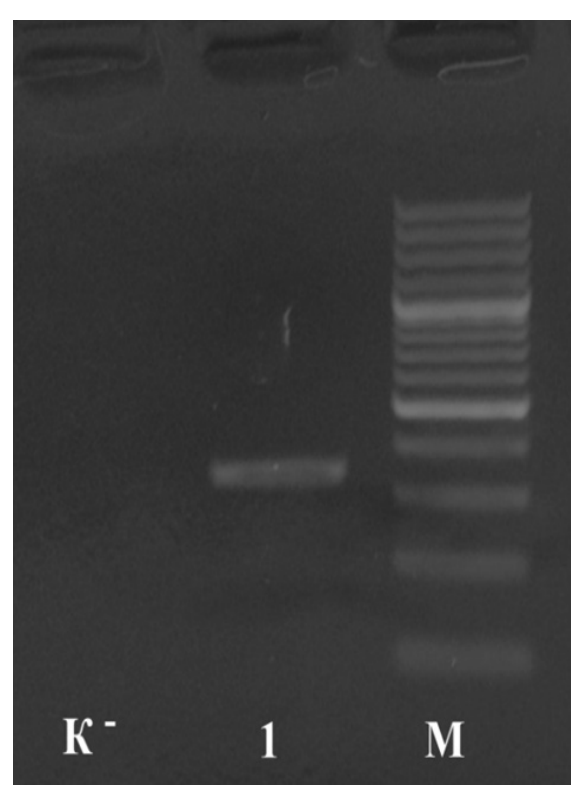

\section{F i g. 2. Agarose gel electrophoresis of RT-PCR amplification products: lane 1 , negative control; lane 2, extracts from symptomatic bean; lane $M, 100$-bp marker}

BCMV has a 260/280 absorbance ratio of 1.27 and the ultraviolet-absorption (UV) spectrum of the virus was recorded spectrophotometrically. UV spectrum of purified BCMV (Fig. 3a) showed a typical curve for nucleoprotein with $\mathrm{A}_{260}$ peak and $\mathrm{A}_{240}$ minimum. Electron micrographs of negativelystained purified preparations of BCMV particles revealed the presence of flexible and filamentous virus particles approximately $740-750 \mathrm{~nm}$ in length and $12-15 \mathrm{~nm}$ in width (Fig. 3b). The particles were similar in morphology to those produced by typical BCMV strain.

The knowledge of virus physical properties is the necessary information for the basic viral characterization and management of the virus diseases. In determining the DEP, infective sap was subjected to serial dilutions and inoculated on bean seedlings following mechanical transmission method along with undiluted control. The inoculated plants showed typical symptoms of virus infection at $10^{-1}, 10^{-2}, 10^{-3}$ and $10^{-4}$ dilutions and also in undiluted control. No symptoms were noticed in further diluted sap at $10^{-5}, 10^{-6}$ and $10^{-7}$. Thus, as shown in Table 1 , virus isolates has a DEP of $10^{-5}$. This value was very close to DEP $10^{-3}-10^{-4}$ reported for BCMV what could be explained by variation among the strains of the same virus. 


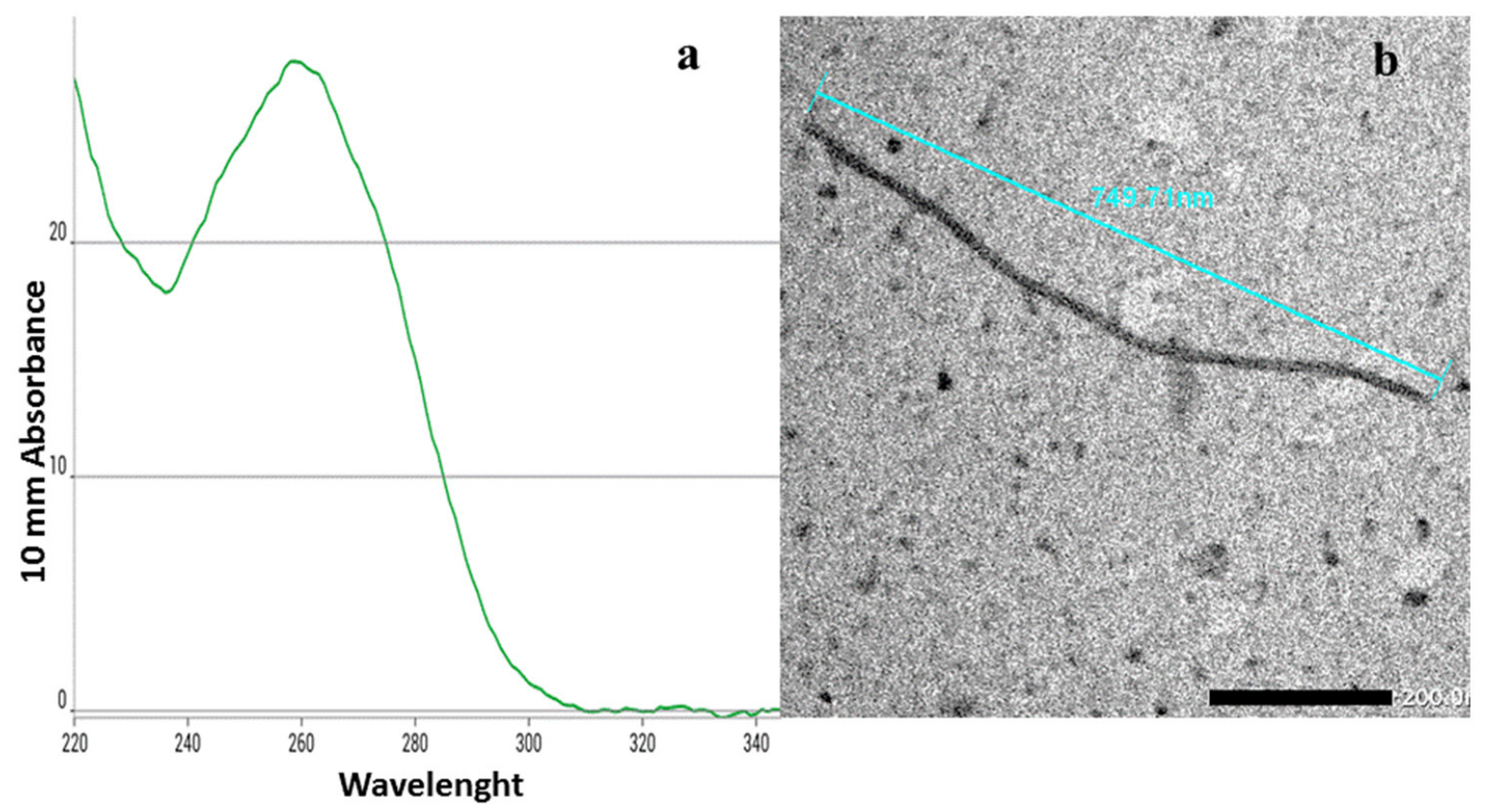

F i g. 3. Electron micrograph showing filamentous particles of BCMV in purified preparation. The virus 4 applied at a concentration of $0.01 \mathrm{mg}$, stained with $2 \%$ uranyl acetate (magnification of $10000 \mathrm{X}$ ).

Table 1

Effect of different sap dilution on infectivity of BCMV

\begin{tabular}{|l|c|c|}
\hline Dilution & Symptoms observed & $\mathbf{N}_{0}$ of days to express symptoms \\
\hline $10^{-1}$ & Mo, Lr, Cvb & $13-14$ \\
\hline $10^{-2}$ & Mo, Lr, Cvb & 15 \\
\hline $10^{-3}$ & Mo, Lr, Cvb & 15 \\
\hline $10^{-4}$ & Mo, Lr, Cvb & 15 \\
\hline $10^{-5}$ & Mo, Lr, Cvb & 15 \\
\hline $10^{-6}$ & - & - \\
\hline $10^{-7}$ & - & - \\
\hline Control & Mo, Dc, Cvb & 13 \\
\hline
\end{tabular}

Legend: Mo - mosaic; $\mathrm{Lr}$ - leaf rolling, $\mathrm{Cvb}$ - chlorotic vein banding; Dc - downward curling.

Table 2

Effect of different temperatures on infectivity of BCMV

\begin{tabular}{|l|c|c|}
\hline Temperature $\left({ }^{\circ} \mathbf{C}\right)$ & Symptoms observed & $\mathbf{N}_{\mathbf{0}}$ of days to express symptoms \\
\hline Untreated sap inoculation & $\mathrm{Mo}, \mathrm{Lr}, \mathrm{Cvb}$ & $13-14$ \\
\hline 35 & $\mathrm{Mo}, \mathrm{Lr}, \mathrm{Cvb}$ & 14 \\
\hline 40 & $\mathrm{Mo}, \mathrm{Lr}, \mathrm{Cvb}$ & 14 \\
\hline 45 & $\mathrm{Mo}, \mathrm{Lr}, \mathrm{Cvb}$ & 14 \\
\hline 50 & $\mathrm{Mo}, \mathrm{Lr}, \mathrm{Cvb}$ & 15 \\
\hline 55 & $\mathrm{Mo}, \mathrm{Lr}, \mathrm{Cvb}$ & 14 \\
\hline 60 & $\mathrm{Mo}, \mathrm{Lr}, \mathrm{Cvb}$ & 16 \\
\hline 65 & - & - \\
\hline 70 & - & - \\
\hline 80 & - & - \\
\hline
\end{tabular}

Legend: Mo - mosaic; Lr - leaf rolling, $\mathrm{Cvb}$ - chlorotic vein banding; Dc - downward curling. 
Determinations of TIP indicated that BCMV isolate had the inactivation point of $65^{\circ} \mathrm{C}-\mathrm{BCMV}$ particles in crude sap are inactivated after heating for 10 minutes at $65^{\circ} \mathrm{C}$. It was shown positive reaction on inoculation by the sap treating at 35$60^{\circ} \mathrm{C}$ temperatures. Plants showed typical symptoms of virus infection: downward curling, yellow mosaic, light and dark-green patches on the leaf. The symptoms appeared from $14^{\text {th }}$ to $16^{\text {th }}$ days after inoculation. Virus failed to produce any symptoms on assay host in case of they were inoculated with sap treated at $65^{\circ} \mathrm{C}$. The TIP values obtained for the virus was acceptable for BCMV [1] and indicated a fairly high level of virus stability to temperature.

In test for determining the longevity in vitro it was shown that infective sap stored at $4^{\circ} \mathrm{C}$ expressed symptoms of virus infection on beans after 3 days of storage but further storage reduced the infectivity and failed to produce any symptoms on plants. This indicates that extracts stored in the fridge for more than 3 days cannot be used in the work. The aging ability for BCMV isolates was determined at $20-25^{\circ} \mathrm{C}$ room temperatures. The isolate remained stable in vitro for 3-4 days. This was in agreement with the known stability in vitro for BCMV which is usually $1-4$ days.

The virus purification procedure used in the study helped to minimize the aggregation of the virus particles and loss of the virus and lead to virus preparation relatively free of host contaminants. The purified virus particles had an $\mathrm{A}_{260 / 280}$ ratio of 1.27 and the yields were approximately $4 \mathrm{mg} / 100 \mathrm{~g}$ of leaf tissue. Electron microscopy of the purified virus preparations showed that the particles were flexuous rods with an average dimension of 740$750 \times 12-15 \mathrm{~nm}$, similar to typical strain of BCMV. The date obtained corresponds with those reported for BCMV in the literature [12, 13].

The results of the research of BCMV isolate physical properties differ a little from those obtained for the typical strain [14]. TIP and LIV of viruses described early were $56-58^{\circ} \mathrm{C}$ and 1 day respectively $[15,16]$. Such differences may be owing to strain diversity or recombination events that occur continuously during the virus evolution.

Conclusions. Due to the fact that biophysical properties are the major criteria for discriminating between virus strains, the dates obtained in the study are necessary characteristics of viruses that could help researchers in managing the diseases and other related studies. Also the findings are useful for a mechanical transmission procedure conducting.

\section{ФІЗИЧНІ ВЛАСТИВОСТІ ВІРУСУ ЗВИЧАЙНОЇ МОЗАЇКИ КВАСОЛІ, ПОШИРЕНОГО В УКРАЇНІ}

\author{
А. М. Кириченко, В. О. Приліпко \\ Інститут мікробіології і вірусології \\ ім. Д.К. Заболотного НАН Украӥни, \\ вул. Академіка Заболотного, 154, \\ Київ, 03143, Україна \\ Резюме
}

Вірус звичайної мозаїки квасолі (ВЗМК) один 3 найбільш поширених вірусів, які вражають бобові культури, належить до родини Potyviridae. У даній роботі представлені результати вивчення фізичних властивостей ізоляту ВЗМК, поширеного в Україні. Методи. Візуальна діагностика, біологічне тестування вірусу, електронна мікроскопія, полімеразна ланцюгова реакція зі зворотною транскрипцією (ЗТ-ПЛР). Результати. У рослин з явними симптомами вірусної інфекції за допомогою ЗТ-ПЛР було встановлено наявність ВЗМК. Вірус був очищений з інфікованих тканин квасолі за модифікованою методикою, що включала в себе освітлення екстракту з додаванням 2,5\% Тритона X-100, концентрування методом центрифугування в лінійному 10-50 \%-ному градієнті сахарози в $0,1 \mathrm{M}$ Трис-тіогліколевій кислоті. Вихід очищеного вірусу становив 3-4 мг із 100 г інфікованого листя. Визначення фізичних властивостей показало, що неочищений вірус втрачав свою інфекційність при нагріванні до $60-65^{\circ} \mathrm{C}$ впродовж 10 хвилин, граничне розведення соку становило $10^{-4}$. Вірус зберігав інфекційність в соку квасолі 3-4 доби за кімнатної температури $(+20-$ $\left.25^{\circ} \mathrm{C}\right)$ і 1-2 дні за $+4^{\circ} \mathrm{C}$. Вірусний ізолят являє собою довгі гнучкі ниткоподібні частинки розміром приблизно 740-750 нм. Висновки. Отримані результати є невід'ємною частиною характеристики виділеного ізоляту ВЗМК і можуть бути використані при плануванні стратегій менеджменту вірусної інфекції.

Ключові слова: вірус звичайної мозаїки квасолі, полімеразна ланцюгова реакція зі зворотною транскрипцією, точка температурної інактивації, граничне розведення соку, період збереження інфекційності in vitro. 
1. Morales FJ, Bos L. Bean common mosaic virus. No. 337. In: Descriptions of Plant Viruses. Association of Applied Biologists, Wellesbourne, England. 1988. http://www.dpvweb.net/dpv/ showadpv.php?dpvno=337

2. Fauquet C, Mayo MA, Maniloff J, Desselberger U, Ball LA. Virus Taxonomy: Eighth Report of the International Committee on Taxonomy of Viruses. In: Fauquet C, Mayo MA, Maniloff J, Desselberger U, Ball LA. The Eighth Report of the International Committee on Taxonomy of Viruses. San Diego, CA USA: Elsevier Academic Press; 2005.

3. Iwanowski D, Ueber die Mosaik Krankheit der Tabakspflanze. Imp Akad Nauk Izv. (Acad Imp Sei St Petersbourg But); 1894; 35(3):67-70.

4. McKern NM, Mink GI, Barnett OW, Mishra A, Whittaker LA, Silbernagel MJ, et al. Isolates of bean common mosaic virus comprising two distinct potyviruses. Phytopathology. 1992; 82:923-929.

5. Drijfhout E, Morales F. Bean Common Mosaic. In: Compendium of bean diseases. 2nd ed. Scwartz HF, Steadman JR, Hall R, Forster RL, editors. The American Phytopathological Society: St. Paul:MN; 2005. p. 60-62.

6. Feng X, Myers JR, Karasev AV. Bean common mosaic virus isolate exhibits a novel pathogenicity profile in common bean, overcoming the bc-3 resistance allele coding for the mutated eIF4E translation initiation factor. Phytopathology. 2015; 105:1487-1495.

7. Kyrychenko AN, Kovalenko AG. [Bean common mosaic in the Kiev region: etiology of disease and pathogen identification]. Mikrobiol $\mathrm{Z}$. 2018; 80(4):96-107. Ukrainian. doi: https://doi. org/10.15407/microbiolj80.04.096
8. Kyrychenko A, Shcherbatenko I, Mishchenko L. BCMV-ukr: isolate of Bean common mosaic virus revealed in Ukraine. Arch Phytopathology Plant Protect. 2019; 52(11-12):1005-1017 https://doi.org/10.1080/03235408.2019.1688448.

9. Huttinga H. Properties of viruses of the potyvirus group. 1. A simple method to purify bean yellow mosaic virus, pea mosaic virus, lettuce mosaic virus and potato virus Y Neth J P1 Path. 1973; 79:125-129.

10. Udayashankar AC, Nayaka C, Niranjana SR, Lund OS, Prakash HS. First report of Bean common mosaic virus infecting lablab purpureus in India. Plant Disease. 2011; 7:881. doi: 10.1094/PDIS-01-11-0009.

11. Noordam D. Identification of Plant Viruses: Methods and Experiments. Centre for Research and Documentation. Wageningen. 1973. p. 5055. https://doi.org/10.1007/BF02360391

12. El-kady MAS, Badr AB, El-Attar AK, Waziri HMA, Saker KEA. Characterization and molecular studies of Bean common mosaic virus isolated from bean plants in Egypt. Egyptian J Virol. 2014; 11(2):124-135.

13. Smith, K.M. A Textbook of Plant Virus Diseases, 3rd ed. Longmans Green: New York; 1972.

14. Brunt AA, Crabtree K, Dallwitz MJ, Gibbs AJ, Watson L, Zurcher EJ, editors. Plant Viruses Online: Descriptions and Lists from the VIDE Database. Version: 20th August 1996. URL http://biology.anu.edu.au/Groups/MES/vide/

15. Nelson R. Investigations in the mosaic disease of bean (Phaseolus vulgaris L.). Mich Agr Expt Sta Tecji Bull. 1932; 118, 71 p.

16. Pierce WH. Viruses of the bean. Phytopathology. 1934; 24:87-15.

Received 26.12.2019 